\title{
MECHANISM OF STATE REGULATION OF MEDICAL RESPONSE TO EMERGENCIES AS AN ELEMENT OF THE CIVIL PROTECTION SYSTEM
}

DOI: 10.36740/WLek202105133

\author{
Petro B. Volianskyi ${ }^{1}$, Volodymir M. Yakymets' ${ }^{2}$ Anna V. Terentieva', Hennadiy 0. Slabkiy ${ }^{3}$, Oleksandr S. Tverdokhlib', \\ Vyacheslav P. Pechyborshch ${ }^{2}$ \\ IINSTITUTE OF PUBLIC ADMINISTRATION AND RESEARCH IN CIVIL PROTECTION, KYIV, UKRAINE \\ 2STATE SCIENTIFIC INSTITUTION «CENTER FOR INNOVATIVE MEDICAL TECHNOLOGIES OF THE NATIONAL ACADEMY OF SCIENCES OF UKRAINE», KYIV, UKRAINE \\ 3UZHHOROD NATIONAL UNIVERSITY, UZHHOROD, UKRAINE
}

\begin{abstract}
The aim: Conducting a comprehensive analysis on ensuring the mechanism of state regulation of the development of medical emergency response as an element of the civil protection system of Ukraine in the context of dynamic changes of external and internal factors of its functioning.

Materials and methods: The data of the state statistical reporting for the period 2010-2019 and the legislative acts of Ukraine on medical emergency response were used as the materials of study. Bibiliosemantic and statistical method and the method of structural-and-logical analysis were applied in the course of study.

Conclusions: The sustainable socio-economic development of Ukraine should be accompanied by the formation of a safe environment for the society and each individual, guaranteeing an acceptable level of risk and a modern security system based on the principles of international law. The high degree of the Ukrainian industry concentration is currently in a conflict with the low technological discipline of production, which creates objective preconditions for the growth of man-made and technologically-environmental disasters, catastrophes, and other emergencies. Outbreaks of particularly dangerous and infectious diseases, which are of concern not only because of their prevalence but also because of the potential danger to the health of the nation, its economy and international reputation of the state can pose a significant threat to the socio-political and socioeconomic stability of the state. Ukraine is a potentially vulnerable area for epidemics due to a number of natural, geographical and geopolitical factors. Therefore, the health consequences (real and potential) of any emergency are certainly a threat to the national security of Ukraine both directly and due to the extremely negative impact on the socio-economic, socio-political and psychological conditions of the population.

Increasing the level of public administration for medical emergency response will increase the effectiveness of emergency response measures.
\end{abstract}

KEY WORDS: civil protection, regulation, emergency situations.

\section{INTRODUCTION}

The last decades of human history have been marked by the occurrence of a significant number of emergencies of natural, anthropogenic and socio-political nature, which were accompanied not only by material but also, unfortunately, substantial human losses.

In Ukraine, the average mortality rate resulted from emergencies is $130-135$ individuals per 100,000 population, which exceeds the corresponding figures in the European countries by 3-5 times. At the same time, about $24 \%$ of victims die in hospitals, and $76 \%$ - at the prehospital stage. According to similar indicators in the developed world, $72 \%$ of victims die in hospitals and only $28 \%$ - at the pre-hospital stage $[1,2]$.

There is a significant number of explosive and fire-hazardous facilities on the territory of Ukraine. Hazardous chemical facilities, which are located at a short distance from the residential areas where about $26 \%$ of the population live, are of particular concern, and there is a threat of possible chemical contamination. About 10,000 tons of gunpowder and 8,000 tons of explosives are stored in the arsenals, bases and warehouses of the Armed Forces throughout Ukraine and the capacity of ammunition storage sites is on average one and a half times higher than the accepted and approved norms.

The issue of storage of the toxic components of rocket fuel remains burning. At most of the storage facilities, the service life of special tanks has expired, and therefore, there is an immediate threat to individuals' life and health from the negative impact caused by the environmental pollution. Highlighting the issue of terrorism in the international dimension has really emphasized the narrowness of the technological and natural dimension of safety and added other danger factors, primarily biological.

Emergencies tend to affect the lives of large areas of the population. For this reason, there is a high probability of a significant number of victims requiring emergency medical care (EMC). In this case, to prevent a large number of irreversible sanitary losses there should be a set of measures on medical protection of victims against emergencies of natural or technogenic nature, which includes medical evacuation, sanitation and anti-epidemic measures, as 
Table 1. Quantitative indicators of the classified emergencies that occurred on the territory of Ukraine during 2010-2019.

\begin{tabular}{|c|c|c|c|c|c|c|c|c|c|c|c|c|}
\hline № & Region of Ukraine & 2010 & 2011 & 2012 & 2013 & 2014 & 2015 & 2016 & 2017 & 2018 & 2019 & Total \\
\hline 1 & $\begin{array}{l}\text { The Autonomous } \\
\text { Republic of Crimea }\end{array}$ & 12 & 4 & 18 & 3 & 1 & & & & & & 38 \\
\hline 2 & Vinnytsia & 9 & 7 & 6 & 3 & 6 & 5 & 4 & 7 & 3 & 4 & 54 \\
\hline 3 & Volyn & 4 & 7 & 1 & 8 & 6 & 6 & 10 & 5 & 6 & 7 & 60 \\
\hline 4 & Dnipropetrovsk & 17 & 10 & 5 & 3 & 6 & 5 & 8 & 4 & 9 & 9 & 76 \\
\hline 5 & Donetsk & 35 & 29 & 25 & 20 & 20 & 7 & 6 & 24 & 10 & 10 & 186 \\
\hline 6 & Zhytomyr & 8 & 6 & 10 & 3 & 5 & 5 & 8 & 5 & 5 & 8 & 63 \\
\hline 7 & Zakarpattia & 9 & 5 & 5 & 7 & 4 & 5 & 6 & 9 & 8 & 7 & 65 \\
\hline 8 & Zaporizhia & 10 & 11 & 8 & 4 & 7 & 5 & 1 & 3 & 4 & 3 & 56 \\
\hline 9 & Ivano-Frankivsk & 8 & 4 & 3 & 3 & 2 & 3 & 5 & 7 & 2 & 7 & 44 \\
\hline 10 & Kyiv & 9 & 7 & 13 & 4 & 3 & 13 & 5 & 6 & 6 & 7 & 73 \\
\hline 11 & Kirovohrad & 3 & 3 & 3 & 2 & 2 & 2 & 6 & 3 & 3 & 4 & 31 \\
\hline 12 & Luhansk & 26 & 18 & 13 & 11 & 7 & 3 & 4 & 5 & 9 & 7 & 103 \\
\hline 13 & Lviv & 11 & 14 & 20 & 14 & 7 & 4 & 6 & 3 & 5 & 8 & 92 \\
\hline 14 & Mykolaiv & 9 & 12 & 11 & 7 & 7 & 7 & 10 & 8 & 8 & 5 & 84 \\
\hline 15 & Odesa & 14 & 17 & 13 & 10 & 9 & 7 & 14 & 13 & 5 & 11 & 113 \\
\hline 16 & Poltava & 3 & 2 & 3 & 5 & 5 & 8 & 10 & 5 & 4 & 10 & 55 \\
\hline 17 & Rivne & 5 & 11 & 4 & 3 & 5 & 4 & 6 & 10 & 2 & 5 & 55 \\
\hline 18 & Sumy & 5 & 4 & 5 & 6 & 4 & 7 & 7 & 3 & 5 & 5 & 51 \\
\hline 19 & Ternopil & 3 & 9 & 8 & 3 & 7 & 5 & 2 & 3 & 6 & 4 & 50 \\
\hline 20 & Kharkiv & 14 & 11 & 11 & 8 & 10 & 9 & 6 & 10 & 4 & 3 & 86 \\
\hline 21 & Kherson & 19 & 6 & 15 & 4 & 10 & 4 & 5 & 9 & 7 & 4 & 83 \\
\hline 22 & Khmelnytsk & 11 & 6 & 6 & 4 & 5 & 4 & 4 & 2 & 3 & 2 & 47 \\
\hline 23 & Cherkasy & 4 & 4 & 9 & 4 & 2 & 5 & 3 & 9 & 5 & 1 & 46 \\
\hline 24 & Chernivtsi & 11 & 1 & 2 & 2 & 1 & 4 & 7 & 5 & 2 & 5 & 40 \\
\hline 25 & Chernihiv & 7 & 7 & 6 & 5 & 8 & 9 & 8 & 3 & 5 & 5 & 63 \\
\hline 26 & Kyiv City & 4 & 4 & 9 & 8 & 3 & 14 & 7 & 12 & 7 & 5 & 73 \\
\hline 27 & Sevastopol City & 3 & 1 & 1 & 1 & 1 & & & & & & 7 \\
\hline 28 & Outside Ukraine & & 1 & & & & & & & & & 1 \\
\hline Tot & emergencies, including: & 254 & 221 & 212 & 144 & 143 & 148 & 149 & 166 & 128 & 146 & 1711 \\
\hline & chnological disasters & 135 & 134 & 120 & 76 & 74 & 63 & 56 & 50 & 48 & 60 & 816 \\
\hline & Natural disasters & 108 & 77 & 74 & 56 & 59 & 77 & 89 & 107 & 77 & 81 & 805 \\
\hline & Social disasters & 11 & 10 & 18 & 12 & 10 & 8 & 4 & 9 & 3 & 5 & 90 \\
\hline \multicolumn{13}{|c|}{ among which, in particular: } \\
\hline & state level & 5 & 4 & 1 & 1 & 5 & 2 & 1 & 2 & 2 & 2 & 25 \\
\hline & regional level & 16 & 3 & 13 & 12 & 9 & 9 & 9 & 8 & 6 & 7 & 92 \\
\hline & local level & 107 & 89 & 83 & 58 & 59 & 62 & 64 & 70 & 64 & 63 & 719 \\
\hline & object level & 126 & 125 & 115 & 73 & 70 & 75 & 75 & 86 & 56 & 74 & 875 \\
\hline & people died & 361 & 355 & 301 & 253 & 287 & 242 & 183 & 172 & 168 & 199 & 2521 \\
\hline & people affected & 753 & 985 & 861 & 854 & 680 & 962 & 1805 & 892 & 839 & 1492 & 10123 \\
\hline & $\begin{array}{l}\text { material losses, } \\
\text { UAH million }\end{array}$ & 984,70 & 102,75 & 249,79 & 396,33 & 198,85 & 532,72 & 265,31 & 896,80 & 496,97 & 685,27 & 4809,49 \\
\hline
\end{tabular}

well as medical supplies. At the same time, these measures should be carried out within the shortest possible periods and by special, professionally trained units $[3,4]$.
The analysis of this issue in the context of modern military conflicts, as well as during a special period, shows that sanitary losses among the civil population are $93-95 \%$ of 
total number of sanitary losses and require the availability of appropriate medical units, stocks of medical equipment, medicines, sufficient number of beds and personnel greater than the calculations for sanitary losses from peacetime emergency situations $[5,6,7,13,14]$.

Among the main shortcomings of the existing subsystem of medical protection within the unified state system of civil protection (USSCP) the following ones can be identified: there is no centralized institution (headquarters) that would coordinate the activities of various services in providing medical care to victims in case of an emergency; there is a problem of medical evacuation of victims to medical institutions that is the effective organization of triage is not worked out, which negatively affects the number of the rescued; there is no centralized system of pre-medical care training of the population; pre-medical care directly in the emergency zone needs to be under legislative regulation.

\section{THE AIM}

The purpose of this study is to carry out comprehensive analysis, generalization and systematization of approaches to ensure an effective and efficient mechanism of state regulation development of medical response to emergencies of natural, anthropogenic and socio-political nature as an element of the USSCP in circumstances of dynamic changes of external and internal factors of its functioning. The main emphasis in the paper is focused on identifying the systemic shortcomings in this area of public administration and on the development of the appropriate recommendations for their elimination in order to improve this subject area.

\section{MATERIALS AND METHODS}

The development of any state in view of the dynamic transformations in the field of science and technology is impossible without development, testing and implementation of the various types of innovative technologies - industrial, agricultural, military, etc. However, there is a constant risk of the various types emergency occurrence, which can potentially lead to damages of local and global scale.

According to the data presented in the research [10, p. 11-15], in our country the technogenic accidents and disasters annually take the lives of about 50,000 citizens, and the largest number of them are in the industrial regions of Ukraine, in particular, Zaporizhia, Donetsk, Dnipropetrovsk, Luhansk, Lviv and Odesa oblasts. Thus, in the structure of people mortality the third place is occupied by accidents, injuries and poisonings. Every year in Ukraine it would be possible to save $30,000-50,000$ people if timely medical care were provided.

The statistical data below is to illustrate and confirm the points mentioned above for the period of last 10 years are given in Table 1 [8]. (Table 1).

The specification of the data provided is presented in the analytical review on technological and natural safety status in Ukraine in 2018, according to which among 128 disasters that occurred during 2018, almost half of them
(61) are medical and biological in which 744, 839 people were injured, 47 people out of 168 died [1, p. 204].

The current, comprehensive systematized legislation - the Civil Protection Code of Ukraine [9] - governs relations concerning the protection of the population, territories, environment and property against emergencies by responding to them and by functioning of the USS CP. It defines the public authority powers, citizens' rights and responsibilities in the field.

However, the analysis of the legislation for medical protection in emergencies has showed its imperfection and inconsistency in terms of civil protection and health care; lack of proper, specific and detailed legal framework, which regulates timely and appropriate medical care to victims directly in the emergency zone, as well as the fact that the inadequate control over its enforcement has led to many shortcomings in the implementation of the measures on elimination of health impacts of disasters in recent years.

The authors $[10$, p. 26] emphasize that "during the first days and months of the armed conflict in eastern Ukraine, the entire burden of providing medical care and evacuation of wounded servicemen, soldiers from volunteer battalions and civilians rested on the shoulders of emergency (ambulance) brigades of the Emergency and Disaster Medicine Centres and their subdivisions on a territorial basis". This underlines the importance of considering the issues raised.

\section{REVIEW AND DISCUSSION}

In Ukraine, the Emergency Medical Services (UEMS) was established in 1990 to provide medical care to the population during the cases of disasters and natural emergencies. In 1997, the State Disaster Medicine Service (SDMS) was established to form a single state system of emergency medical care in Ukraine with the main task of providing free medical care to the citizens in extreme situations (natural disasters, catastrophes, accidents, mass poisonings, epidemics, epizootics, radiation, bacteriological and chemical contamination, etc.).

The management and organization of SDMS work should be supported by a reasonable combination of the UEMS centralized governing at the pre-hospital stage, medical evacuation and victims' hospitalization by appointment, qualified and specialized emergency medical care with decentralized management to overcome health impacts of emergencies.

The centralization of UEMS management was implemented in a functional subsystem of the Government Information and Analytical System on Emergencies within the powers of the Ministry of Health of Ukraine with the managirial decisions and information transfer at all levels of emergency response.

The organizational structure of the UEMS assumed two levels of the government: central and territorial. The central level of government included specially designated medical forces and facilities of the Ministry of Health of Ukraine, central executive bodies and health authorities of administrative territories operated in any region of Ukraine after 
Table 2. Phased provision of medical care to victims in Ukraine

\begin{tabular}{|c|c|c|c|c|}
\hline \multirow{2}{*}{$\begin{array}{c}\text { Phases of } \\
\text { medical care } \\
\text { Place of medical } \\
\text { care }\end{array}$} & \multicolumn{2}{|c|}{ Pre-hospital } & \multirow{2}{*}{$\begin{array}{c}\text { Early hospital } \\
\begin{array}{l}\text { Admission department } \\
\text { of health care facilities }\end{array}\end{array}$} & \multirow{2}{*}{$\begin{array}{c}\text { Hospital } \\
\text { Clinical departments of } \\
\text { health care facilities }\end{array}$} \\
\hline & Emergency zone & Emergency zone boundary & & \\
\hline $\begin{array}{l}\text { Type of medical } \\
\text { care }\end{array}$ & $\begin{array}{l}\text { Pre-hospital aid } \\
\text { (The Law of Ukraine "On } \\
\text { emergency medical care") }\end{array}$ & $\begin{array}{l}\text { Emergency medical care } \\
\text { (The Law of Ukraine "On } \\
\text { the basics of the legislation } \\
\text { of Ukraine on health care") }\end{array}$ & $\begin{array}{l}\text { Secondary medical care } \\
\text { (The Law of Ukraine } \\
\text { "On the basics of the } \\
\text { legislation of Ukraine } \\
\text { on health care") }\end{array}$ & $\begin{array}{l}\text { Tertiary medical care (The } \\
\text { Law of Ukraine "On the } \\
\text { basics of the legislation of } \\
\text { Ukraine on health care") }\end{array}$ \\
\hline $\begin{array}{l}\text { Medical care } \\
\text { providers }\end{array}$ & $\begin{array}{l}\text { Rescuers, } \\
\text { firefighters, } \\
\text { volunteers }\end{array}$ & $\begin{array}{c}\text { Ambulance crews, } \\
\text { first-line disaster medicine } \\
\text { service crews, } \\
\text { mobile medical centres } \\
\text { of the State Emergency } \\
\text { Service of Ukraine }\end{array}$ & $\begin{array}{c}\text { second-line disaster } \\
\text { medicine service crews, } \\
\text { admission department } \\
\text { staff }\end{array}$ & $\begin{array}{l}\text { Clinical department staff } \\
\text { of health care facilities }\end{array}$ \\
\hline $\begin{array}{l}\text { Medical care } \\
\text { capacity }\end{array}$ & $\begin{array}{l}\text { Initial medical triage } \\
\text { Professional life support }\end{array}$ & $\begin{array}{c}\text { Medical triage } \\
\text { Emergency care Medical } \\
\text { evacuation }\end{array}$ & $\begin{array}{l}\text { Qualified medical care } \\
\text { with the elements of } \\
\text { the specialized one }\end{array}$ & $\begin{array}{l}\text { Specialized medical care } \\
\text { Medical and } \\
\text { psychological } \\
\text { rehabilitation }\end{array}$ \\
\hline $\begin{array}{l}\text { Medical care } \\
\text { timeframe }\end{array}$ & $\begin{array}{c}\text { up to } 60 \mathrm{~min} \\
\text { (so-called «golden hour») }\end{array}$ & $\begin{array}{l}0-72 \text { hours } \\
\text { (the time is specified } \\
\text { considering search and } \\
\text { rescue works) }\end{array}$ & $1-24$ hours & $1-90$ days \\
\hline $\begin{array}{l}\text { Medical } \\
\text { care } \\
\text { is regulated }\end{array}$ & $\begin{array}{l}\text { Orders of the Ministry of } \\
\text { Health of Ukraine: "On } \\
\text { approval of the procedures } \\
\text { for the provision of pre- } \\
\text { hospital care to individuals } \\
\text { in medical emergency", } \\
\text { "On improving training of } \\
\text { individuals without medical } \\
\text { background in pre-hospital } \\
\text { care" }\end{array}$ & $\begin{array}{l}\text { Medical standards } \\
\text { Clinical protocols } \\
\text { Order of the Ministry } \\
\text { of Health of Ukraine } \\
\text { "On approval and } \\
\text { implementation } \\
\text { of medical and } \\
\text { technological documents } \\
\text { on standardization of } \\
\text { emergency medical care" }\end{array}$ & $\begin{array}{l}\text { Medical standards } \\
\text { Clinical protocols }\end{array}$ & $\begin{array}{l}\text { Medical standards } \\
\text { Clinical protocols }\end{array}$ \\
\hline Logistics support & $\begin{array}{l}\text { Individual first aid kit. } \\
\text { Car first aid kit }\end{array}$ & $\begin{array}{l}\text { Report card of material and } \\
\text { technical equipment of the } \\
\text { unit }\end{array}$ & $\begin{array}{l}\text { Report card of } \\
\text { material and technical } \\
\text { equipment of the } \\
\text { department }\end{array}$ & $\begin{array}{c}\text { Report card of material } \\
\text { and technical equipment } \\
\text { of the department }\end{array}$ \\
\hline
\end{tabular}

disasters strike. It was taken into account that the territorial medical forces and means of the disaster medicine service from the relevant administrative unit (including its mobile units) could not liquidate the health consequences of the emergency.

The territorial level of the government included medical forces and means of the administrative-territorial bodies of health authorities as well as forces and means of medical institutions under the central executive bodies, local private or public medical institutions aimed at managing health consequences of emergencies in the territories concerned (the Autonomous Republic of Crimea, oblasts, and directly governed municipalities).

The main institutions of the UEMS were: at the central level - the Ukrainian Scientific and Practical Centre for Emergency Care and Disaster Medicine, USPCEC and DM (now - the State Institution "Ukrainian Scientific and Practical Centre for Emergency Care and Disaster Medicine of the Ministry of Health of Ukraine", USPCEC and DM of the
Ministry of Health $\mathrm{f}$ Ukraine); at the territorial level - the territorial centres of emergency medical care and disaster medicine as legal entities of double subordination directly accountable to the Ministry of Health of the Autonomous Republic of Crimea, the Department of Health Care in oblast, Kyiv and Sevastopol cities state administrations, functionally - to USPCEC and DM.

Since the beginning of 2013, the Law of Ukraine "On Emergency Medical Care" (EMC) came into force, which defines: organizational and legal principles of securing the emergency medical service to the residents and non-residents of Ukraine; the principles of organization and functioning of the EMC system; powers of authorities and local self-government in the field; the legal status of the EMC centres, operational and dispatching services of these centres, stations and crews of EMC; the social rights and guarantees for EMC employees; financial, logistical and scientific support for the operation of the EMC system.

This legal act on the issues of disaster medicine intro- 
Emergency notification

(nature, scale, place and time of the event)

Determination of the health consequences of emergencies

(irrecoverable and recoverable sanitary losses, prognosis of long-term medical consequences)

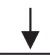

Setting on higher alert of mobile medical units
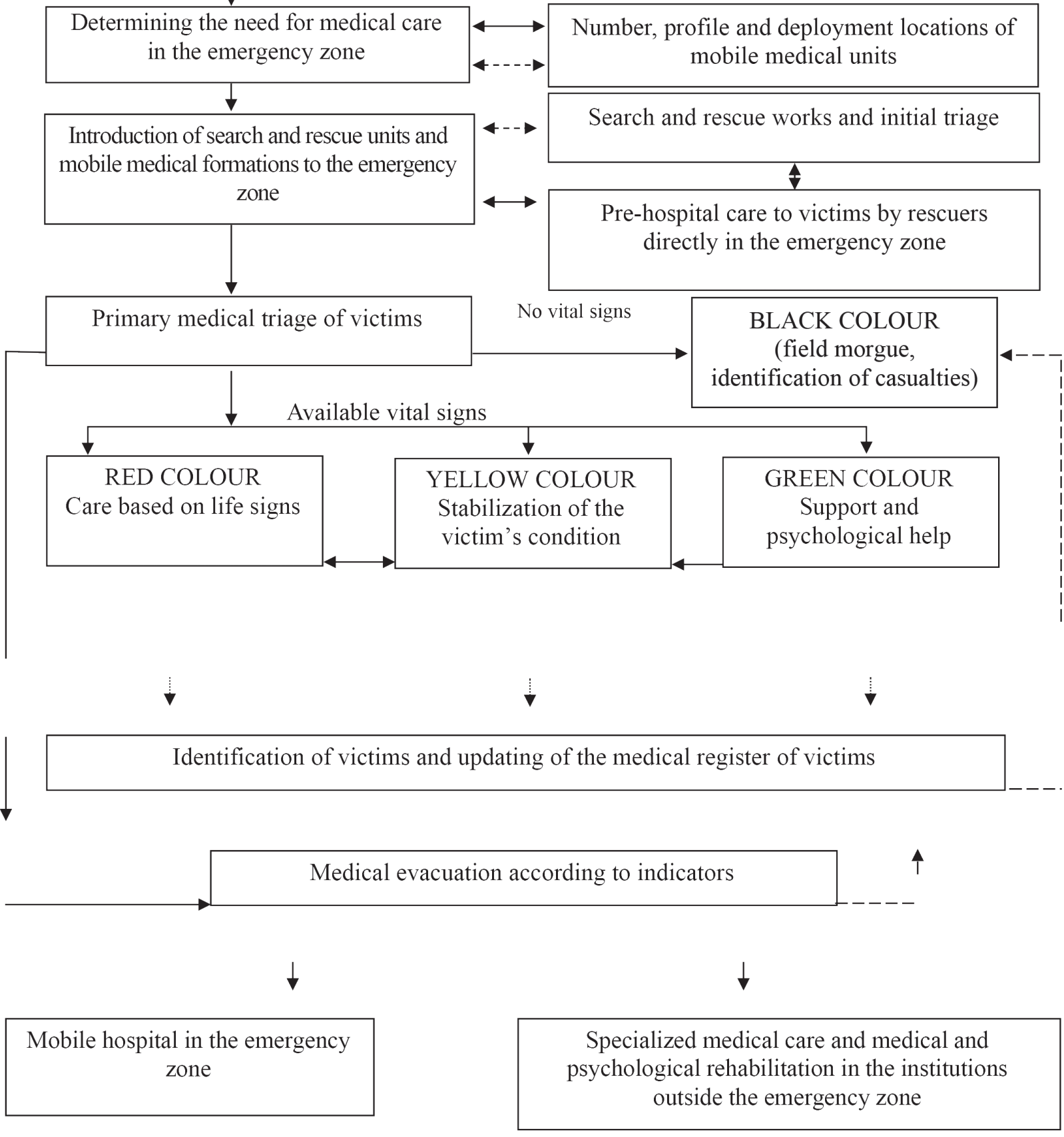

Fig. 1. Organizational and functional scheme of medical response to emergencies 
duced some radical changes. In particular, the notions concerning the State Disaster Medicine Service (SDMS) and its central level were actually (indirectly) eliminated. Along with the elimination of these concepts, the legitimacy of the existence and further functions of the institutions and units at the central level of the State Disaster Medicine Service remained an open issue. This also includes the main mobile medical unit of the SDMS - a mobile hospital of the State Emergency Service of Ukraine, as well as the main institution at this level - the State Institution "The Ukrainian Scientific and Practical Centre for Emergency Care and Disaster Medicine of the Ministry of Health of Ukraine".

It should be noted that SDMS of Ukraine as a civil service is a subsystem of the Unified State System of Civil Protection and is developed at the central and regional levels. The centralization of the structure stems from the fact that any dangers caused by state-level emergencies require the immediate centralized administration of all civil protection forces (including medical), as well as the ability to mobilize more forces than any regional service can immediately do.

The Code of Civil Protection of Ukraine defines disaster medicine services as a special type of the emergency services which operate as part of the EMC centres and DM of the UEMC system and are established by the authorities of the Autonomous Republic of Crimea, oblasts, the cities of Kyiv and Sevastopol.

At the same time, the medical protection, sanitary and epidemic well-being includes medical care to victims given by rescuers and other people involved in the implementation of rescue and other urgent work during the disaster response. The medical care is provided by the Disaster Medicine Service, which is managed by the central executive body. The latter ensures the development and implementation of the government policy in the field of health care. Thus, the Ministry of Health of Ukraine establishes and manages the Disaster Medicine Service, which was previously considered the central level of the State Disaster Medicine Service.

Currently, the disaster medicine services of the Emergency Medicine Services of the Territorial Centres and Emergency Medicine have not been established yet. The existing provisions of the regulations of the Cabinet of Ministers of Ukraine, departmental orders of the Ministry of Health of Ukraine concerning fulfillment of the functions assigned to SDMS at the territorial level, as well as to its institutions, units and their structural subdivisions, are not based on the requirements of the Civil Protection Code of Ukraine. They relate to the formations and structures of the inactive SDMS and, therefore, are not fully implemented.

With the adoption of the Law of Ukraine "On Emergency Medical Care" there was a distinction between the types of medical care and categories of people who provide medical care to victims, namely: pre-hospital care and emergency medical care.

Thus, pre-hospital care for people during the emergencies should be provided by rescuers, firefighters, police, pharmacists, railway conductors, flight attendants and other people who in relation to their official duties are obliged to possess the appropriate skills.

It should be emphasized that the basic principles of the medical care organization during disasters include: the establishment of the coordination centre in the emergency zone, which provides the medical and evacuation support for victims; the maximum utilization of the local network of health-care facilities; regular medical units involvement at the pre-hospital stage that are able to provide a complete medical care within a specific time frame; mandatory inclusion of specialized inpatient facilities in the structure of the disaster medicine service.

A phased approach to delivering medical care to victims in Ukraine is presented in Table 2. (Table 2)

Afterwards, based on the developed organizational model of managing medical care when overcoming the health consequences of emergencies with a significant concentration of people [13], taking into consideration the analysis of the scientific resources $[3,12,5,11]$ we have developed an organizational and functional scheme of medical response to emergencies (Fig. 1).

Should an emergency arise, the work of the health protection authorities from the first minutes of the event must be aimed at providing the emergency medical care: mobilized the medical staff; mobile units of the disaster medicine service, which are sent to the emergency centre; the supply of medicine and medical equipment is provided; medical evacuation of casualties is arranged; as well as order on the roads and uninterrupted flow of transport.

The implementation of the current legislation, which is a basis for organization and provision of medical care to casualties is possible if common approaches to the organization of the medical evacuation service during disasters are developed $[3,4,5]$. This will allow the responsible bodies to make emergency medical assistance to victims affected by emergencies more effective; to avoid the development of injury and disease complications, thus, to preserve human health; to reduce the workload of ambulance crews and keep up the pace of their daily work.

\section{CONCLUSIONS}

The establishment of the State Disaster Medical Service was justified and met the needs and objectives of public administration in the field of civil protection at that time. The further area of development proved that the substantiation of the principles of the state regulation mechanism of medical response to emergencies would allow the authorities (responsible institutions) to optimize the public administration of overcoming the health consequences of emergencies both in Ukraine and abroad. At the same time, the health care management system remains unstructured, in particular due to its non-standardization as a corresponding functional subsystem of the Unified State System of Civil Protection, which is subordinated to the central executive body in the field of health care. Some inconsistency of management functions has now led to the de facto liquidation of the State Emergency Medical Service 
of Ukraine and the distribution of the functions on the medical protection between the central executive bodies. However, the larger the scope of the disaster, the higher the requirements to administration and management, thus, the final result of the emergency response greater depends on the effective administration and management in the field.

\section{REFERENCES}

1. Analitychnyi ogliad stanu texnogennoi ta pryrodnoi bezpeky v Ukraini za 2018 rik. DSNS Ukrainy, UkrNDICZ. [Analytical review of the biological and technical threats` state in Ukraine during 2018]. https://www.dsns. gov.ua/files/prognoz/report/2018/A0_2018.pdf. (in Ukrainian).

2. Volianskyi P.B. Vyznachennia resursnykh potreb pry podolanni medyko-sanitarnykh naslidkiv nadzvychainykh sytuatsii pryrodnoho i tekhnohennoho pokhodzhennia. [Determining resource needs during solving medical outcomes of emergencies of technogenic and biological nature]. Efektyvnist derzhavnoho upravlinnia. 2012; 30:177-183. (in Ukrainian).

3. Volianskyi P.B. Kontseptsiia derzhavnoho upravlinnia medychnym zakhystom u zoni nadzvychainykh sytuatsii. [Concept of state managing of medical care in areas of emergencies]. Investytsii: praktyka ta dosvid. 2013; 14: 127 - 8. (in Ukrainian).

4. Volianskyi P.B. Teoretychni zasady derzhavnoho upravlinnia medychnym zakhystom naselennia vid naslidkiv nadzvychainykh sytuatsii v Ukraini [Theoretical basis of state managing of medical care for population that suffered from emergencies]. Kyiv: In-t zakonodavstva Verkhovnoi Rady Ukrainy; 2013; 39. (in Ukrainian).

5. Volianskyi P.B. Upravlinnia medychnym zakhystom naselennia i terytorii v nadzvychainykh sytuatsiiakh: monohrafiia. [State managing of medical care for population and territories in emergencies: monograph]. Kyiv; 2013; 360. (in Ukrainian).

6. Huriev S.0., Pechyborshch V.P., Mykhailovskyi M.M. Normatyvnopravove zabezpechennia reformuvannia systemy medychnoho zakhystu naselennia za umov nadzvychainykh sytuatsii v Ukraini: stan ta problemy realizatsii. [Legal framework for reform in system of medical care for population in emergencies in Ukraine: current stage and problems of realization]. Mater. of 16th Ukrainian nauk.-prakt. konf. Riatuvalnykiv. 2014; 88. (in Ukrainian).

7. Huriev S.0., Radysh Ya.F., Terentieva A.V. Kryzovyi menedzhment ta upravlinnia nadzvychainymy sytuatsiiamy v derzhavnomu upravlinni. [Crisis situation management and regulation of emergencies in the system of state managing]. Universytetski naukovi zapysky. 2009; 2: 285-90. (in Ukrainian).

8. Zvit pro osnovni rezultaty diialnosti Derzhavnoi sluzhby Ukrainy z nadzvychainykh sytuatsii u 2019 rotsi. [Report on results of work of State organization of emergencies in 2019]. Uriadovyi portal. Yedynyi veb-portal orhaniv vykonavchoi vlady Ukrainy. https://www.kmu.gov. ua/storage/app/sites/1/17-civik-2018/zvit_2019/zvit-2019-dsns.pdf (in Ukrainian).

9. Kodeks tsyvilnoho zakhystu Ukrainy: Zakon, Kodeks vid 02.10.2012 № 5403-VI. [Code of Civil Protection of Ukraine: Law, Code from 02.10.2012 N 5403-VI]. Baza danykh "Zakonodavstvo Ukrainy". Verkhovna Rada Ukrainy. https://zakon.rada.gov.ua/go/5403-17 (in Ukrainian).

10. Pechyborshch V.P., Volianskyi P.B., Yakymets B.M. et al. Optymizatsiia diialnosti Derzhavnoi sluzhby medytsyny katastrof: kerivnytstvo. [Work optimization of the State agency of medical emergencies: guidelines]. Kyiv: SPD Chalchynska NV. 2019; 1: 396. (in Ukrainian).
11. Reahuvannia na nadzvychaini sytuatsii: navch. posib. [Emergencies reacting: manual]. DSNS Ukrainy, In-t derzh. upr. u sferi tsyv. zakhystu. Kyiv: Blank-Pres; 2014; 205. (in Ukrainian).

12. Terentieva A.V. Derzhavne upravlinnia medychnym zakhystom za umov nadzvychainykh sytuatsii pryrodnoho i tekhnohennoho kharakteru [State managing of medical care during emergencies caused by technogenic or biological factors]. Kyiv: Nats. akad. derzh. upr. pry Prezydentovi Ukrainy; 2010; 36. (in Ukrainian).

13. Shostak L.Y. Mekhanizmy zabezpechennia vzaiemodii subiektiv derzhavnoi systemy likvidatsii medyko-sanitarnykh naslidkiv nadzvychainykh sytuatsii [Mechanisms of providing interaction of subjects in liquidation of medical outcomes of emergencies process]. Odesa: Odes. rehion. in-t derzh. upr. Nats. akad. derzh. upr. pry Prezydentovi Ukrainy; 2014; 20. (in Ukrainian).

14. Shostak L.Y. Orhanizatsiia vzaiemodii tsentralnykh ta mistsevykh orhaniv vykonavchoi vlady pry likvidatsii medyko-sanitarnykh naslidkiv nadzvychainykh sytuatsii. [Organization of interaction of central and local executive power representatives to liquidate medical outcomes of emergencies]. Naukovyi visnyk Akademii munitsypalnoho upravlinnia. Seriia "Upravlinnia". 2012; 2: 325-33. (in Ukrainian).

The study is a part of the institutional research project entitled "Investigation of Methods for Civil Protection Force Liaison in Emergencies", state registration № 0119 U000479.

\section{ORCID and contributionship:}

Petro B. Volianskyi: 0000-0002-7992-8260 A, B, C, D, E Volodymir M. Yakymets: 0000-0002-5407-4609 A, C, D Anna V. Terentieva: 0000-0003-3881-5865 A, B, C, D, E, F Hennadiy O. Slabkiy: 0000-0003-2308-7869 A, B,D

Oleksandr S. Tverdokhlib: 0000-0002-1502-2937 A, B, C, D, F Vyacheslav P. Pechyborshch: 0000-0003-4280-8297 A, B, C, D

\section{Conflict of interest:}

The Authors declare no conflict of interest.

\section{CORRESPONDING AUTHOR}

\section{Anna V. Terentieva}

Center for innovative medical technologies

of the National Academy of Sciences of Ukraine

54Vladimirskaya st., 01030 Kyiv, Ukraine

tel.: 067745 4476;

e-mail:teren_a@ukr.net

Received: 11.12 .2020

Accepted:01.04.2021

A - Work concept and design, B - Data collection and analysis, C - Responsibility for statistical analysis, D -Writing the article, E-Critical review, $\mathbf{F}$ - Final approval of the article 